DOI 10.37882/2223-2982.2020.10.08

\title{
ОСОБЕННОСТИ СИСТЕМЫ МАНСАБДАРИ В ИМПЕРИИ ВЕЛИКИХ МОГОЛОВ ВО ВРЕМЕНА ПРАВЛЕНИЯ ПАДИШАХА АКБАРА
}

\section{FEATURES OF THE MANSABDARI SYSTEM IN THE MUGHAL EMPIRE DURING THE REIGN OF PADISHAH AKBAR \\ T. Vasilenko}

Summary: the purpose of the study is to determine the key features of the mansabdari system and track the causes of its occurrence based on factual material from narrative sources. The article reveals the principles of organization of the Mughal army during the reign of padishah Akbar. The scientific novelty of the research lies in the author's view of the reasons for the emergence of the mansabdari system in medieval India and the analysis of the features of the mansabdari system during the reign of Akbar. As a result of the study, it was found that the mansabdari system was a kind of attempt to combine the state and military traditions of the Delhi Sultanate with the principles of organizing the troops of the Genghisid and Timurid empires.

Keywords: Akbar's reforms, Mughal Empire, padishah Akbar, mansabdari, mansabdar.
A ктуальность темы обусловлена тем, что политике Акбара в военной сфере уделяется недостаточное внимание в историографии. В эпоху английского колониального господства в Индии армия империи Моголов считалась архаичным войском отсталой восточной деспотии. Кроме того, исследователи традиционно обращают меньшее внимание на военный аспект деятельности Акбара по сравнению с его религиозной политикой. Именно благодаря своей мощной армии Моголы могли проводить успешные завоевательные военные кампании и противостоять государствам-соперникам. Хотя отцом-основателем державы Моголов и был падишах Бабур, но настоящим создателем армии могольской империи стал падишах Акбар, создавший систему мансабдари, которая была одним из фундаментов могущества державы Моголов. Вопрос о причинах появления и корнях системы мансабдари остается и по сегодняшний день открытым, а потому он представляет большой интерес для ученых-историков. Стоит заметить, что в историографии недостаточно исследована связь экономических преобразований Акбара с его военными реформами.

Для достижения указанной цели исследования необходимо решить следующие задачи: проанализировать

\author{
Василенко Тарас Никитич \\ Киевский национальный университет имени Тараса \\ Шевченко, г. Киев, Украина \\ taras18641@gmail.com
}

Аннотация: Цель исследования - опираясь на фактологический материал из нарративных источников, определить ключевые особенности системы мансабдари и отследить причины ее возникновения. В статье раскрываются принципы организации войска империи Моголов во времена правления падишаха Акбара. Научная новизна исследования заключается в авторском взгляде на причины возникновения системы мансабдари в средневековой Индии и анализе особенностей системы мансабдари во времена правления Акбара. В результате исследования было установлено, что система мансабдари стала своеобразной попыткой соединить государственные и военные традиции Делийского султаната с принципами организации войска империй Чингизидов и Тимуридов.

Ключевые слова: реформы Акбара, Империя Великих Моголов, падишах Акбар, мансабдари, мансабдар.

источниковую базу исследования, проанализировать принципы организации войска империи Моголов до прихода Акбара к власти, установить особенности системы мансабдари во времена правления Акбара, сформулировать возможные причины появления системы мансабдари.

Для определения ключевых особенностей системы мансабдари в статье применяются следующие методы исследования: историко-сравнительный, описательный и аналитический.

Теоретической базой исследования служат работы таких авторов, как: К. Антонова [8, с. 238-242], Л. Алаев [7, с. 166-167], М. Джафар [1, р. 159-160], Н. Синха [10, с. 231-232], С. Шандра [2, р. 236-239], В. Смит [3, р. 354], в которых описывается ход военной реформы Акбара и раскрываются основные особенности системы мансабдари.

Имеющаяся база источников позволяет подробно исследовать и анализировать историю военных преобразований Акбара. Ключевым источником по истории правления Акбара является летопись «Акбар-наме» [5; 6], составленная придворным летописцем и истори- 
ографом Абу-л Фазлом. Абу-л Фазл, будучи одним из приближенных Акбара, всячески возвеличивает деятельность падишаха, часто прибегая к откровенной лести. Впрочем, в «Акбар-наме» содержится обширный фактологический материал о правлении и жизни Акбара.

Главным источником для данной статьи стала работа «Аин-и-Акбари» [4], которая, по сути, является полноценным описанием империи Моголов. Автором «Аин-и-Акбари» также является Абу-л Фазл. Так как война оказывала колоссальное влияние на политическую жизнь средневековой Индии, то значительная часть «Аин-и-Акбари» посвящена именно описанию армии Великих Моголов. Также в «Аин-и-Акбари» содержится подробнейшая информация об особенностях системе мансабдари.

Еще одним важнейшим источником по военной истории Индии XVI века является труд «Бабур-наме» [9] - автобиографическая работа, написанная Бабуром, основателем империи Моголов. В «Бабур-наме» раскрывается специфика ведения боевых действий в Индии XVI века, состав армии самого Бабура и некоторые особенности организации армии позднего Делийского султаната. Также «Бабур-наме» раскрывает нам причины победы Бабура в битве при Панипате.

Практическая значимость исследования заключается в том, что результаты исследования, проведенного при написании данной статьи, могут быть использованы в педагогический деятельности, при проведении лекций и семинаров, посвященных периоду правления Акбара.

В 1556 г., на момент прихода Акбара к власти, армия империи Моголов, в целом, была преемником вооружённых сил Делийского султаната. Могольское войско во времена правления Хумаюна и Бабура состояло из отрядов наемной кавалерии, которые формировались и возглавлялись помещиками-джагирдарами. Те получали от государства во временное пользование земельный надел - джагир. За счет налогов, собранных из своих владений, джагирдары должны были содержать себя и снаряжать определенное количество воинов (остальную часть налогов они должны были передавать в государственную казну). Но джагирдары не удерживали на постоянной службе необходимое число солдат, а деньги, предназначенные для выплат бойцам, забирали себе. Джагирдары собирали свои отряды только на время военных кампаний, а как только война заканчивались, то они сразу же распускали своих воинов.

Подобная армия не имела эффективной системы командования, о централизованном управлении боевыми действиями и речи идти не могло, ведь каждый военачальник действовал по своему усмотрению. Боеспособность такого войска почти целиком зависела от удачи командира, кроме того, армия, состоявшая из джагирдарских отрядов, очень легко покидала поле боя и разбегалась [8, с. 149]. Правитель чрезвычайно зависел от поддержки джагирдаров, ведь иначе он мог оказаться без войска.

Необходимость решительного реформирования военной системы Индии ярко продемонстрировала битва при Панипате 1526 г. Бабуру удалось легко разгромить войско султана Ибрагима, которое насчитывало сто тысяч воинов и тысячу боевых слонов [9, с. 207]. Победу Бабур одержал благодаря использованию пушек (до Бабура в полевых сражениях артиллерия в Индии не применялась). Также Бабур использовал кочевую тактику маневренного боя, с которой воины Делийского султаната были незнакомы.

Стоит отметить, что в XVI веке в военном искусстве исламского Востока происходят значительные изменения. Большую роль в боевых действиях начинает играть огнестрельное оружие, а сами принципы войсковой организации усложняются, в армиях государств Востока появляются регулярные подразделения. Процесс модернизации войска первой завершила Османская Империя, что позволило ей разбить Сефевидов в Чалдыранской битве в 1514 г. и одержать победу в войне с Мамлюками в 1516-1517 гг. Поэтому можем говорить, что армии Моголов были необходимы срочные реформы, иначе она была бы не способна противостоять своим противникам.

Изменения в военной сфере начались с изданного в 1574 г. указа об обязательном клеймении лошадей [6, с. 181]. Это решение не было новшеством для Индии, до Акбара аналогичный закон принял Шер-шах, а до Шершаха - султан Ала ад-Дин Хилджи [5, с. 30]. Указ о клеймении лошадей был направлен против джагирдаров, которые на регулярные военные смотры приводили своих слуг, или вообще на время нанимали случайных людей вместо настоящих солдат (часто два командира, договорившись между собой, обменивались воинам на время смотра и выставляли одних и тех же всадников). Клеймение лошадей тавром падишаха или отдельного военачальника позволяло избежать подобных махинаций.

Также в 1574 г. Акбар пытается провести налоговую реформу, при которой джагирдарские землевладения были переведены в государственный земельный фонд халисе, а сами джагирдары и их воины были переведены на денежное содержание [6, с. 181]. Абу-л Фазл сообщает, что военачальникам и их слугам была назначена денежная плата, а их (военачальников) ранг определялся согласно заслугам и размерам войска [Там же, с. 181]. Стоит отметить, что поскольку первая налоговая реформа Акбара провалилась, то полностью перевести армию на денежное содержание у падишаха не получилось. 
Главным новшеством военной реформы Акбара стало введение общей службы реестра и уникальной системы рангов. «Величайшим нововведением стала служба реестра. Эта идея пришла в голову Его Величества в момент, когда судьба улыбалась ему. Был издан указ, согласно которому обязательному учету подлежало все, что отправлялось со двора, чтобы военачальники могли получить денежное вознаграждение, и выполняли административные приказы», - пишет Абу-л Фазл [Там же, c. 182].

Все представители элиты могольского государства и, в первую очередь, офицеры и джагирдары (ранговая система Империи Моголов была построена по военному образцу) получили определенный ранг - мансаб [3, р. 332]. «Его Величество ввел должности мансабдаров от дахбашы (десятника) до даххазари (командира десяти тысяч), назначив своих сыновей командирами отрядов, в которых служило более пяти тысяч воинов» [4, с. 379].

Каждый мансабдар получал от государства плату, объем которой зависел от его ранга (или мансабдар получал от государства джагир, но Акбар старался не раздавать земельные наделы, а выплачивать солдатам денежное жалование) [11, с. 232]. За счет полученных от государства средств или доходов со своих владений мансабдар должен был снаряжать определенное количество воинов, лошадей и слонов в соответствии со своим рангом. Такая система комплектования войск, на первый взгляд, схожа с той, что существовала в империи ранее, но теперь военачальники находились под более серьезным государственным контролем. Разумеется, почти все мансабдары не могли содержать нужное число бойцов, а потому каждый мансабдар имел два ранга личный (зат) и воинский (савар) [Там же, с. 231].

Зат определял место конкретного человека в иерархии Империи Моголов, а также размер денежного вознаграждения, которое получал этот человек от государства (например, чины мансабдаров имели наложницы из гарема падишаха для того, чтобы можно было определить, сколько им платить) [7, с. 166].

Савар же устанавливал реальное количество воинов, которых должен выставлять мансабдар [Там же, с. 166]. Объем ежемесячных выплат, которые получал мансабдар из государственной казны, зависел от количества солдат, находившихся под его началом. Например, офицер, размер отряда которого соответствовал его мансабу, относился к первому классу [4, с. 379]. Военачальники, которые удерживали половину или более воинов от необходимого количества считались командирами второго класса, а офицеры, руководившие отрядами численностью менее половины мансаба, состояли в третьем классе [Там же, с. 379].
Например, юзбаши (сотники) вообще делились на одиннадцать классов. К первому классу относились те офицеры, руководившие отрядом из ста воинов, а к одиннадцатому те командиры, вообще не имевшие в подчинении ни одного бойца [Там же, с. 379]. Сотники первого класса получали 700 рупий ежемесячно, а сотники последнего класса всего 500 рупий. Для сотников промежуточных классов устанавливалась плата в 700 рупий, которая уменьшалось на 20 рупий за каждые 10 недостающих воинов [Там же, с. 379].

Всего в государстве Моголов существовало 66 мансабов (возможно, что Абу-л Фазл допустил ошибку, ведь в перечне мансабдаров в «Аин-и-Акбаре» указано лишь 33 мансаба) [Там же, с. 379]. Вся армия государства Моголов подчинялась военному ведомству, во главе которого стоял мир бахши (или бахши) [1, р. 143]. Бахши отвечал за набор солдат, выплату жалования, поставки провианта и вооружения для армии, руководил войсками на поле боя. Сама армия Моголов была разделена на тысячи, сотни и десятки. Например, командирам (мансабдарам) десяти тысяч подчинялись мансабдары в ранге хазари (mысячники) [4, с. 373]. В подразделениях командира восьми тысяч служили мансабдары в ранге хаштсади (командиры восьми сотен), в подразделениях командиров семи тысяч служили офицеры в ранге хафтсади (командиры семи сотен), в подразделениях командиров пяти тысяч служили военачальники в ранге пансади (командиры пяти сотен), а в отрядах, возглавляемых пансади, служили мансабдары в ранге саду (сотники) [Там же, с. 373].

Учитывая, что Абу-л Фазл перечисляет в «Аин-и Акбари» имена офицеров, руководивших подразделениями, в которых насчитывалось более 200 воинов, можно предположить, что во времена Акбара такие командиры имели право на почетный титул амира [Там же, с. 373]. Титулом амир-ул-Умара (амир амиров или верховный амир), который, если судить по названию, мог принадлежать только одному человеку, награждались несколько вельмож [Там же, с. 380].

Военная и административная иерархия империи Великих Моголов не имеет никаких аналогов в других государствах Востока и является уникальным для Индии явлением. С. Шандра считает, что, возможно, корни системы мансабдари следует искать в армии империи Чингизидов, которая была организована по десятичному принципу [2, р. 237]. Также на могольскую военную организацию могла повлиять военная система Делийского султаната, в которой существовали должности сотника (саду) и тысячника (хазари), а во времена правления династии Суров в султанате были джагирдары, которые назначались командирами 20000, 10000 или 5000 саваров [Там же, р. 237]. Однако говорить о существовании в Индии чего-то похожего на могольскую ранговую систему до прихода к власти Акбара мы не можем. 
Возможно, появление системы мансабдари стало результатом смешения военных традиций Делийского султаната и Средней Азии, откуда прибыли сами Моголы. Десятичная организация войска, четкая иерархия и дисциплина принесли армиями Чингисхана и Тимура ряд побед (войско Бабура, с которым он покорил Индию, была по организации и составу очень похоже на армию Тимура), но полностью перенести принципы организации кочевого войска в Индию, где сотни лет действовала практика раздачи джагиров, сформировались специфические государственные институты, было невозможно. Поэтому система мансабдари стала попыткой совместить военные традиции кочевых империй со старыми принципами военной организации Делийского султаната. Джагирдарские отряды продолжали составлять основную часть войска, но армия Моголов теперь была организована по десятичному принципу, большинство воинов были переведены на денежное содержание, что сделало их зависимыми от государства и позволило ввести четкую армейскую иерархию.

Таким образом, мы приходим к следующим выводам. Военная реформа Акбара была вызвана необходимостью создания более действенной системы организации армии, чем та, что действовала в Делийском султанате. Могольский падишах не мог зависеть от джагирдарских ополчений, которые показали свою неэффективность в битве при Панипате. Империя Моголов нуждалась в регулярных воинских отрядах, которые подчинялись бы самому падишаху. Кроме того, в начале XVI века в воинском искусстве стран Востока существенно выросла роль артиллерии и ручного огнестрельного оружия. Армия, состоящая из джагирдарского ополчения, уже не соответствовала вызовам времени.

Проведение структурных изменений в военной сфере стало возможным лишь после существенного реформирования экономики империи Моголов. Налоговая и финансовая системы державы Моголов, созданные Акбаром, позволяли перевести армию на денежное жалование и прекратить практику раздачи джагиров.

Однако в Индии сотни лет существовала джагирдарская система. Уничтожить ее Акбар не мог, что и продемонстрировала его первая неудачная налоговая реформа. Поэтому падишах ввел в империи Моголов ранговую систему мансабдари, которая позволила совместить индийские военные традиции с принципами военной организации кочевых империй, обуздать джагирдаров и определить размеры жалования, выплачиваемого государством мансабдарам, оптимизировав таким образом государственные расходы. Система мансабдари стала уникальным явлением для империи Моголов, ее возникновение стало возможным благодаря смешению в Индии различных государственнических и военных традиций. Можно уверенно утверждать, что система мансабдари была одним из основных фундаментов империи Моголов.

\section{ЛИТЕРАТУРА}

1. Jaffar. M. The Mughal Empire from Babur to Aurangzeb. Peshawar: Kissa Khani, 1926. 441 p.

2. Satish Chandra. History of medieval India. New Dheli: Orient BlackSwan, 2007. 418 p.

3. Smith Vincent Arthur, Edwardes Stephen Meredyth. The Oxford history of India, from the earliest times to the end of 1911. Oxford: The Clarendon Press, 1919. $816 \mathrm{p}$.

4. Абу-л Фазл Аллами. Аин-и-Акбари. Избранные главы: в 7 кн. / Перевод с английского С.В. Сливашкин // Абу-л Фазл Аллами. Акбар-наме / Перевод с английского: И.О. Клубкова, А. Е. Дунаев. Самара: Агни, 2003. Книга 5. С. 373-397.

5. Абу-л Фазл Аллами. Акбар-наме: в 7 кн. / Перевод И.0. Клубкова, А. Е. Дунаев. Самара: Агни, 2003. Кн. 5. 400 с.

6. Абу-л Фазл Аллами. Акбар-наме: в 7 кн. / Перевод И.0. Клубкова, А.Е. Дунаев. - Самара: Агни, 2003. Кн. 2.368 с.

7. Алаев Л.Б. Средневековая Индия. Санкт-Петербург: Алтейя, 2003. 304 с.

8. Антонова. К.А. Очерк общественных отношений и политического строя могольской Индии времен Акбара. Москва: Издательство Академии Наук СССР, 1952. $283 \mathrm{C}$.

9. Захир ад-Дин Бабур. Бабур-наме / Перевод со староузбекского М. А. Салье. Ташкент: Главная редакция энциклопедий, 1992. 312 с.

10. Синха Н.К., Банерджи А.Ч. История Индии. Москва: Издательство иностранной литературы, 1954.440 с.

(с) Василенко Тарас Никитич (taras18641@gmail.com).

Журнал «Современная наука: актуальные проблемы теории и практики» 